\title{
Pathomechanism of Renal Damage in Type 2 Diabetes Mellitus Patients
}

\author{
Yuliana Sambara ${ }^{1,2 *}$, Mansyur Arief ${ }^{3}$, Uleng Bahrun ${ }^{3}$ \\ ${ }^{1}$ Postgraduate Program in Clinical Biochemistry, Hasanuddin University, Jl. Perintis Kemerdekaan Km.10, Makassar, Indonesia \\ ${ }^{2}$ Prodia Clinical Laboratory, Jl. Hertasning Raya No. 33, Makassar, Indonesia \\ ${ }^{3}$ Faculty of Medicine, Hasanuddin University, Jl. Perintis Kemerdekaan Km.10 Makassar, Indonesia \\ *Corresponding author. E-mail: virginia_yuli05@yahoo.com
}

\section{Abstract}

B

ACKGROUND: Hyperglycemia in diabetic patients cause both chronic inflammation and extracellular matrix accumulation that can lead to progressive renal damage. Albumin, Gammaglutamytransferase (GGT) and clusterin in urine are markers to detect damage in glomerulus, cell of the tubules and proximal tubules, respectively.

METHODS: This study aimed to evaluate the pathomechanism of haemoglobin A1c (HbA1c), albumin, GGT, clusterin, type IV collagen in urine, and highsensitivity C-reactive protein (hsCRP) in type 2 diabetes mellitus (DM) patients. The study was a cross sectional study involving 82 subjects consisting of 36 males and 46 females, 35-65 years old, divided into 3 groups: uncontrolled DM, controlled DM and non DM. Data were obtained from interviews, physical examinations (weight, height, blood pressure) and laboratory examinations ( $(\mathrm{HbAlc}$, serum glutamic oxaloacetic (SGOT), serum glutamic pyruvic (SGPT), creatinine, hsCRP, urinary albumin, urinary GGT, urinary clusterin, and urinary type IV collagen). Statistical analysis was performed for correlation, difference and cross tabulation tests.

RESULTS: The study results showed there were significant differences $(p<0.05)$ between uncontrolled DM group compared with controlled DM and non DM groups in HbAlc, ratio of urinary type IV collagen and ratio of urinary albumin. However, there were no significant differences between controlled DM and non DM groups. There were positive significant correlations between $\mathrm{HbA} 1 \mathrm{c}$ with hsCRP $(\mathrm{r}=0.223, p<0.05), \mathrm{HbA} 1 \mathrm{c}$ with ratio of urinary type IV collagen/creatinine $(\mathrm{r}=0.563, p<0.001), \mathrm{HbAlc}$ with ratio of urinary albumin/creatinine $(\mathrm{r}=0.263, p<0.05)$, and ratio of urinary type IV collagen/creatinine with ratio urinary albumin/creatinine $(\mathrm{r}=0.613, p<0.001)$.

\section{Abstrak}

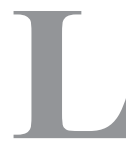

ATAR BELAKANG: Hiperglikemia pada pasien diabetes menyebabkan inflamasi kronis dan akumulasi matriks ekstraselular yang dapat berlanjut menjadi kerusakan ginjal. Albumin, Gammaglutamytransferase (GGT) and clusterin pada urin merupakan penanda untuk mendeteksi kerusakan pada glomerulus, sel tubulus dan tubulus proksimal.

METODE: Penelitian ini bertujuan untuk mengevaluasi patomekanisme hemoglobin Alc (HbAlc), albumin, GGT, clusterin, kolagen tipe IV urin, dan high-sensitivity C-reactive protein (hsCRP) pada pasien diabetes melitus (DM) tipe 2. Penelitian ini merupakan studi cross sectional dengan melibatkan 82 subyek yang terdiri dari 36 lakilaki dan 46 perempuan, usia 35-65 tahun, yang kemudian dibagi menjadi 3 grup: DM tidak terkontrol, DM terkontrol dan non DM. Data didapatkan dari hasil wawancara, pemeriksaan fisik (berat badan, tinggi badan, tekanan darah) dan pemeriksaan laboratorium (HbA1C, serum glutamic oxaloacetic (SGOT), serum glutamic pyruvic (SGPT), kreatinin, hsCRP, albumin urin, GGT urin, clusterin urin, dan kolagen tipe IV urin). Analisa statistik dilakukan untuk tes korelasi, perbedaaan dan tabulasi silang.

HASIL: Hasil penelitian memperlihatkan perbedaan bermakna $(p<0,05)$ antara grup DM tidak terkontrol dengan grup DM terkontrol dan non DM pada pemeriksaan $\mathrm{HbAlc}$, rasio kolagen tipe IV urin and rasio albumin urin. Akan tetapi, tidak ada perbedaan bermakna antara grup DM terkontrol dan non DM. Terdapat korelasi positif yang bermakna antara $\mathrm{HbA1c}$ dengan hsCRP $(\mathrm{r}=0,223, p<0,05)$, $\mathrm{HbA} 1 \mathrm{c}$ dengan rasio kolagen tipe IV urin/kreatinin ( $\mathrm{r}=0,563$, $p<0,001)$, HbAlc dengan rasio albumin urin/kreatinin $(\mathrm{r}=0,263, p<0,05)$, dan rasio kolagen tipe IV urin/kreatinin dengan rasio albumin urin/kreatinin $(\mathrm{r}=0,613, p<0,001)$. 
CONCLUSION: Results of this study indicated that albumin and type IV collagen in urine play a role in renal damage caused by uncontrolled glucose level in subjects with type $2 \mathrm{DM}$. The increased concentration of both $\mathrm{HbAlc}$ and urinary type IV collagen indicates increased risk factor of glomerulus damage. Urinary type IV collagen is likely to be future potential marker for early detection of renal damage.

KEYWORDS: renal damage, HbAlc, hsCRP, type IV collagen, GGT, clusterin, diabetes mellitus
KESIMPULAN: Hasil penelitian mengindikasikan bahwa albumin dan kolagen tipe IV urin berperan dalam kerusakan ginjal yang disebabkan oleh level glukosa tidak terkontrol pada subyek DM tipe 2. Peningkatan konsentrasi HbAlc dan kolagen tipe IV urin mengindikasikan peningkatan faktor risiko kerusakan glomerulus. Kolagen tipe IV urin berpotensi menjadi penanda untuk deteksi awal kerusakan ginjal.

KATA KUNCI: kerusakan ginjal, HbA1c, hsCRP, kolagen tipe IV, GGT, clusterin, diabetes melitus

Indones Biomed J. 2013; 5(3): 161-8

\section{Introduction}

Diabetes mellitus (DM) is characterized by hyperglycemia caused by insulin deficiency and/or insulin resistance.(1) According to the American Diabetes Association in 2010, $\mathrm{DM}$ is a group of metabolic diseases with characteristic hyperglycaemia that occurs due to disorder of insulin secretion, insulin action or both.(2)

Several epidemiological studies have shown a trend of increase in the incidence and prevalence of type $2 \mathrm{DM}$ in many parts of the world. World Health Organization (WHO) has predicted the number of DM patients will sharply increase in the future. WHO and International Diabetes Federation (IDF) have predicted an increase in the number of people with type $2 \mathrm{DM}$ at 2-3 fold in 2030.(2)

DM can lead to microvascular and macrovascular complications as a result of exposure to chronic hyperglycemia.(1,3) Among the microvascular complications, diabetic kidney disease is one of the most serious with a significant impact on morbidity, mortalitiy and quality of life of the sufferers. About $20-40 \%$ of people with DM will progress to diabetic nephropathy $(\mathrm{DN})(2)$, which is a leading cause of end-stage renal disease (ESRD) (4). Deaths due to kidney disease are 17 times more frequent in diabetic patients than in non-diabetic patients.(5)

Clinical studies have demonstrated that high blood glucose is always the main cause of the initiation and progression of diabetic vascular complications including nephropathy. Hiperglycemia induces reactive oxygen species (ROS) formation, activates signal tranduction cascade and transcription factor-induced ROS, over-expression of genes and proteins in the glomerular mesangium, and tubular epithelial cells may result in the accumulation of extracellular matrix (ECM) in diabetic kidney.(6)

A number of clinical and animal studies on inflammatory mechanisms as an important pathogenic factor in diabetic complications including glomerulosclerosis have indicated there was some evidences of the inflammatory role in the progression of tubulointerstital injury in DN. Increase in the circulation of a number of inflammatory markers such as C-reactive protein (CRP), fibrinogen, serum amyloid A protein (SAA), and Interleukin-6 (IL-6) correlated with albuminuria and deposition of ECM proteins in patients with both type 1 and type $2 \mathrm{DM}$, and as such causing increased risk of renal disease progression.(7)

Early renal tubular damage is characterized by increased enzimuria of proximal tubulus such as $\beta-\mathrm{N}$ acetyl-glycosaminidase ( $\beta$-NAG), gamma glutamyl transferase (GGT), lactate dehydrogenase (LDH) and alkaline phosphatase (ALP). Increased urinary enzyme can be used to detect nephrotoxicity and renal disease.(8) The presence of specific enzymes in urine is due to cellular damage caused by cell lysis, necrosis or loss of the luminal membrane of drug-induced.(9)

Clusterin is a glycoprotein involved in many physiological and patho-physiological processes that consists of two types, namely the exogenous secretory type contained in biological fluids, and the endogenous secretory type contained in the cytoplasm and nucleus.(10) Clusterin in renal excretion is prominently found only in the early stages of nephron development, but will then reappear with the various types of acute and chronic injury.(11) Clusterin was identified as a biomarker for kidney injury, especially in the tubular system, because it will be up-regulated in the renal tissue immediately after exposure to toxin.(9)

Studies with animal trials and on the genetic aspects of DM have reported that ECM expansion in the glomerulus exceeds glomerular filtration associated with excessive production of type IV collagen. Type IV collagen is a major component of the glomerular basement membrane and mesangial matrix. A small amount of type IV collagen is excreted into the urine in healthy subjects. $(12,13)$ 
Based on this background, this study was conducted to assess the relationship between Haemoglobin A1c (HbA1C) with hs-CRP and urinary biomarkers (GGT, albumin, clusterin, type IV collagen) in subjects with type $2 \mathrm{DM}$ and to elucidate the pathomechanism of the renal damage involved.

\section{Methods}

\section{Subjects}

Study population were subjects aged 35-65 years with no smoking habit, no alcoholic habit, no heart disease history, no malignancy disease, no anti-inflammatory drugs consumption, with/without type 2 DM. Subjects with hypertension, glomerular flow rate $<60 \mathrm{~mL} /$ minute/ $1.73 \mathrm{~m}^{2}$ (counting with formula of chronic kidney disease epidemiology collaboration), high-sensitivity C-reactive protein (hs-CRP) $\geq 10$, serum glutamic oxaloacetic (SGOT) and/or serum glutamic pyruvic (SGPT) $>2$ fold the upper normal limit, were excluded from the study. The study protocol was approved by the Health Research Ethics Committee, Faculty of Medicine, Hasanuddin University, Makassar (No. UH13030104). All participants were notified about the objectives of study and an informed consent was obtained from each study subjects.

\section{Specimen Collection and Biochemical Analysis}

Blood specimens and second morning urine were collected after an overnight fasting for 10-12 hours. Measurement of anthropometric parameters (waist circumference, height, weight) and blood pressure were carried out. Biochemical variables were done according to in kit insert as follows: concentration of SGOT (Cat. No.: 20764949322, Roche Diagnostics GmbH, Mannheim, Germany), SGPT (Cat. No.:
20764957322, Roche Diagnostics GmbH), urea N (Cat. No.: 4460715190, Roche Diagnostics $\mathrm{GmbH}$ ), serum creatinine (Cat. No.: 3263991190, Roche Diagnostics GmbH), urinary creatinine (Cat. No.: 04992596, Roche Diagnostics GmbH), hs-CRP (Cat. No.: 4628918190, Roche Diagnostics GmbH), urinary albumin (Cat. No.: 03051194, Roche Diagnostics $\mathrm{GmbH}$ ) and HbA1c (Cat. No.: 2200112, Biorad, Richmond, CA). Whereas urinary type IV collagen (Cat. No.: BIO83, Argutus Medical, Dublin, Ireland) and urinary clusterin (Cat. No.: DCLU00, R\&D systems, Inc., Minneapolis, MN) were measured by enzyme immunoassay methods.

\section{Statistical analysis}

Statistical analysis were performed with SPSS for Windows version 16.0 (SPSS Inc., Chicago, IL). Distributions of continuous variables were assessed for normality using Kolmogorov-Smirnov test. Correlation between variables was analyzed using Pearson and Spearman correlation analysis. Independent sample $\mathrm{T}$ test was done for comparison between groups. For the statistical test we used $5 \%$ to define the level of significance. Crosstabs analysis was done to assess the risk factor of parameters increase due to increased levels of $\mathrm{HbAlc}$.

\section{Results}

\section{General characteristics of subjects}

A total of 82 subjects were analyzed, consisting of 65 subjects with DM and 20 subjects with non DM. Subjects with DM with $\mathrm{HbA} 1 \mathrm{c}$ levels $\geq 7 \%$ were categorized as uncontrolled $\mathrm{DM}$ and those with $\mathrm{HbA1c}<7 \%$ were categorized as controlled DM. DM duration of subjects was between 0.5 38 years (median $=3$ years). Characteristics of study subjects and the results of normality test data are shown in Table 1 .

Table 1. General characteristics of subjects and normality test $(n=82)$.

\begin{tabular}{lccccc}
\hline \multicolumn{1}{c}{ Variable } & Min & Max & Mean \pm SD & Median & $\boldsymbol{p}^{*}$ \\
\hline Age $($ year) & 35.00 & 65 & $51.11 \pm 9.09$ & - & $\mathbf{0 . 4 6 1}$ \\
BMI $\left(\mathrm{Kg} / \mathrm{m}^{2}\right)$ & 16.79 & 39.01 & $25.57 \pm 3.59$ & - & $\mathbf{0 . 9 6 8}$ \\
HbA1c $(\%)$ & 4.3 & 16 & - & 7.1 & 0.046 \\
hs-CRP $(\mathrm{mg} / \mathrm{dL})$ & 0.160 & 8.801 & - & 1.338 & 0.003 \\
Urinary Albuin/creatinine $(\mu \mathrm{g} / \mathrm{mg})$ & 3 & 550 & - & 11 & 0.000 \\
Urinary Clusterin (ng/mL) & 5.50 & $1,245.60$ & - & 142.98 & 0.020 \\
Urinary Type IV Collagen/Creatinine $(\mu \mathrm{g} / \mathrm{g})$ & 0.500 & 29 & - & 2.754 & 0.002 \\
Duration of DM (year) & 0.5 & 38 & - & 3 & 0.006 \\
\hline
\end{tabular}

*: distribution assessment with Kolmogorov Smirnov test; BMI: body mass index. 
Table 2. Comparison of biomarkers among groups.

\begin{tabular}{|c|c|c|c|c|}
\hline Variable & $\begin{array}{c}\begin{array}{c}\text { Uncontrolled DM } \\
(\mathrm{n}=42)\end{array} \\
\text { Mean } \pm \mathrm{SD} / \text { Median }\end{array}$ & $\begin{array}{c}\begin{array}{c}\text { Controlled DM } \\
(\mathrm{n}=\mathbf{2 0})\end{array} \\
\text { Mean } \pm \text { SD } / \text { Median }\end{array}$ & $\begin{array}{c}\begin{array}{c}\text { Non DM } \\
(\mathrm{n}=\mathbf{2 0})\end{array} \\
\text { Mean } \pm \mathrm{SD} / \text { Median }\end{array}$ & $p^{*}$ \\
\hline Age (year) & $52.40 \pm 9.01$ & $50.10 \pm 9.78$ & $49.80 \pm 8.72$ & 0.532 \\
\hline $\operatorname{BMI}\left(\mathrm{Kg} / \mathrm{m}^{2}\right)$ & $25.58 \pm 3.38$ & $24.89 \pm 3.52$ & $26.24 \pm 4.14$ & 0.838 \\
\hline HbAlc (\%) & 9.4 & 5.7 & 5.5 & 0.000 \\
\hline hs-CRP (mg/dL) & 1.482 & 1.511 & 1.237 & 0.260 \\
\hline Urinary Albumin/Creatinine ( $\mu \mathrm{g} / \mathrm{mg})$ & 18.5 & 4 & 7 & 0.007 \\
\hline Urinary Clusterin (ng/mL) & 142.02 & 137.05 & 162.38 & 0.819 \\
\hline Urinary Type IV Collagen/Creatinine ( $\mu \mathrm{g} / \mathrm{g}$ ) & 4.23 & 1.85 & 2.12 & 0.002 \\
\hline Duration of DM (year) & 3 & 2.9 & - & 0.001 \\
\hline
\end{tabular}

*: Independent $t$ test between Unctrolled and Controlled DM groups.

Table 3. Correlation analyses between biomarkers.

\begin{tabular}{|c|c|c|c|c|c|c|}
\hline & & $\begin{array}{l}\text { hs-CRP } \\
(\mathrm{mg} / \mathrm{dL})\end{array}$ & $\begin{array}{c}\text { Urinary } \\
\text { Type IV Collagen/Creatinine } \\
(\mu \mathrm{g} / \mathrm{mg})\end{array}$ & $\begin{array}{c}\text { Urinary GGT } \\
(\mathbf{U} / \mathbf{L})\end{array}$ & $\begin{array}{c}\text { Urinary } \\
\text { Albumin/Creatinine } \\
(\mu \mathrm{g} / \mathbf{m g})\end{array}$ & $\begin{array}{l}\text { Urinary } \\
\text { Clusterin } \\
(\mathrm{ng} / \mathrm{mL})\end{array}$ \\
\hline \multicolumn{7}{|l|}{ Total Population $(n=82)$} \\
\hline \multirow[t]{2}{*}{ HbAlc (\%) } & $\mathrm{r}$ & $0.223^{*}$ & $0.513^{* *}$ & -0.189 & $0.263^{*}$ & -0.164 \\
\hline & $p$ & 0.045 & 0.000 & 0.093 & 0.019 & 0.146 \\
\hline \multirow[t]{2}{*}{ hs-CRP (mg/dL) } & $\mathrm{r}$ & 1.000 & 0.173 & -0.029 & 0.180 & -0.008 \\
\hline & $p$ & - & 0.120 & 0.797 & 0.105 & 0.945 \\
\hline \multirow[t]{2}{*}{ Urinary Type IV Collagen/Creatinine } & $\mathrm{r}$ & 0.173 & 1.000 & -0.128 & $0.613^{* *}$ & 0.143 \\
\hline & $p$ & 0.120 & - & 0.253 & 0.000 & 0.200 \\
\hline \multicolumn{7}{|l|}{ Uncontrolled DM $(n=42)$} \\
\hline \multirow[t]{2}{*}{$\mathrm{HbAlc}$} & $\mathrm{r}$ & $0.370^{*}$ & $0.380^{*}$ & $0.314^{*}$ & -0.100 & -0.112 \\
\hline & $p$ & 0.017 & 0.014 & 0.049 & 0.538 & 0.492 \\
\hline \multirow[t]{2}{*}{ hs-CRP } & $\mathrm{r}$ & 1.000 & 0.104 & $0.321^{*}$ & -0.162 & 0.110 \\
\hline & $p$ & - & 0.514 & 0.040 & 0.310 & 0.947 \\
\hline \multirow[t]{2}{*}{ Urinary Type IV Collagen/Creatinine } & r & 0.104 & 1.000 & $0.560^{* *}$ & -0.049 & 0.142 \\
\hline & $p$ & 0.514 & - & 0.000 & 0.762 & 0.374 \\
\hline \multicolumn{7}{|l|}{ Controlled DM (n=20) } \\
\hline \multirow[t]{2}{*}{$\mathrm{HbAlc}$} & $\mathrm{r}$ & -0.173 & -0.133 & -.0 .156 & 0.135 & -0.067 \\
\hline & $p$ & 0.479 & 0.588 & 0.536 & 0.593 & 0.792 \\
\hline \multirow[t]{2}{*}{ hs-CRP } & $\mathrm{r}$ & 1.000 & 0.032 & 0.754 & 0.393 & 0.057 \\
\hline & $p$ & - & 0.892 & 0.077 & 0.096 & 0.817 \\
\hline \multirow[t]{2}{*}{ Urinary Type IV Collagen/Creatinine } & $\mathrm{r}$ & 0.032 & 1.000 & 0.269 & -0.165 & -0.044 \\
\hline & $p$ & 0.892 & - & 0.251 & 0.488 & 0.855 \\
\hline \multicolumn{7}{|l|}{ Non DM $(n=20)$} \\
\hline \multirow[t]{2}{*}{$\mathrm{HbAlc}$} & $\mathrm{r}$ & 0.306 & 0.145 & -0.055 & -0.294 & -0.195 \\
\hline & $p$ & 0.190 & 0.541 & 0.830 & 0.237 & 0.437 \\
\hline \multirow[t]{2}{*}{ hs-CRP } & $\mathrm{r}$ & 1.000 & 0.289 & 0.237 & -0.128 & 0.035 \\
\hline & $p$ & - & 0.217 & 0.313 & 0.591 & 0.885 \\
\hline \multirow[t]{2}{*}{ Urinary Type IV Collagen/Creatinine } & $\mathrm{r}$ & 0.289 & 1.000 & 0.435 & 0.098 & $0.456^{*}$ \\
\hline & $p$ & 0.217 & - & 0.055 & 0.682 & 0.043 \\
\hline
\end{tabular}

Pearson and Spearman correlation analysis. *: $p<0.05 ; * *: p<0.001$ 
Table 4. Crosstabs analysis between HbA1c and urinary albumin.

\begin{tabular}{|c|c|c|c|c|c|c|}
\hline & & \multicolumn{2}{|c|}{ Urinary Albumin } & \multirow{2}{*}{ Total } & \multirow{2}{*}{$p$} & \multirow{2}{*}{ OR } \\
\hline & & $\geq \mathbf{3 0}$ & $<30$ & & & \\
\hline \multirow[t]{4}{*}{$\mathrm{HbA} 1 \mathrm{c} \geq 7$} & $\mathrm{~N}$ & 19 & 23 & 42 & 0 & 7.435 \\
\hline & $\% \mathrm{HbAlc}$ & $45.20 \%$ & $54.80 \%$ & $100.00 \%$ & & \\
\hline & $\%$ Urinary albumin & $82.60 \%$ & $39.00 \%$ & $51.20 \%$ & & \\
\hline & $\%$ Total & $23.20 \%$ & $28.00 \%$ & $51.20 \%$ & & \\
\hline \multirow[t]{4}{*}{$\mathrm{HbAlc}<7$} & $\mathrm{~N}$ & 4 & 36 & 40 & & \\
\hline & $\% \mathrm{HbAlc}$ & $10.00 \%$ & $90.00 \%$ & $100.00 \%$ & & \\
\hline & $\%$ Urinary albumin & $17.40 \%$ & $61.00 \%$ & $48.80 \%$ & & \\
\hline & $\%$ Total & $4.90 \%$ & $43.90 \%$ & $48.80 \%$ & & \\
\hline \multirow[t]{4}{*}{ Total } & $\mathrm{N}$ & 23 & 59 & 82 & & \\
\hline & $\% \mathrm{HbAlc}$ & $28.00 \%$ & $72.00 \%$ & $100.00 \%$ & & \\
\hline & $\%$ Urinary albumin & $100.00 \%$ & $100.00 \%$ & $100.00 \%$ & & \\
\hline & $\%$ Total & $28.00 \%$ & $72.00 \%$ & $100.00 \%$ & & \\
\hline
\end{tabular}

OR: odds ratio

\section{Comparison of Biomarkers among Groups}

Median value of urinary collagen type IV/creatinine ratio was found higher in uncontrolled DM group compared with controlled DM and non DM groups (4.23, 1.85 and 2.12 $\mu \mathrm{g} / \mathrm{mg}$, respectively). There was a significant difference $(p<0.05)$ between uncontrolled DM and controlled DM groups, but no significant difference was noted between controlled and non DM groups. Median value of urinary albumin/creatinine ratio was found higher in uncontrolled DM group compared with controlled DM and non DM groups (18.50, 4 and $7 \mu \mathrm{g} / \mathrm{mg}$, respectively). There was a significant difference $(p<0.05)$ seen between uncontrolled $\mathrm{DM}$ and controlled DM groups, but no significance difference $(p>0.05)$ between controlled DM and non DM groups.

\section{Correlation analyses between Biomarkers (HbA1c, hs-} CRP, Urinary Type IV Collagen, Albumin, GGT and Clusterin)

There was a significant correlation $(p<0.05)$ between HbAlc and hs-CRP, as shown in Table 3. Significant positive correlation $(\mathrm{r}=0.223, p<0.05)$ was shown in total population and uncontrolled DM group $(\mathrm{r}=0.370, p<0.05)$.

There was a significant positive correlation between
HbAlc and urinary type IV collagen/creatinine ratio as a marker of extracellular matrix (ECM) accumulation in total population $(\mathrm{r}=0.513, p<0.001)$ and uncontrolled DM group $(\mathrm{r}=0.380, p<0.05)($ Table 3$)$. There was a positive significant correlation between $\mathrm{HbAlc}$ and urinary albumin/creatinine ratio in total population $(\mathrm{r}=0.263, p<0.05)$. Also we found significant positive correlation between urinary type IV collagen/creatinine ratio and urinary albumin/creatinine ratio $(\mathrm{r}=0.613, p<0.001)$. In uncontrolled $\mathrm{DM}$ group, $\mathrm{HbAlc}$, hs-CRP and urinary type IV collagen/creatinine ratio were all positive significantly correlated with urinary GGT ( $\mathrm{r}=0.314, p<0.05 ; \mathrm{r}=0.321, p<0.05 ; \mathrm{r}=0.560, p<0.001$, respectively).There was a positive significant correlation between urinary type IV collagen/creatinine ratio and urinary clusterin in non DM $(\mathrm{r}=0.456, p<0.05)$. There was no significant correlation found between hs-CRP and urinary type IV collagen/creatinine ratio.

\section{Discussion}

Hyperglycemia in patients with DM can lead to microvascular and macrovascular complications. This condition can lead to increased morbidity and mortality in patients with DM.

Table 5. Frequency Analysis of increase of urinary collagen type IV and urinary albumin.

\begin{tabular}{|c|c|c|c|c|c|c|}
\hline \multirow{3}{*}{$\begin{array}{c}\text { Urinary } \\
\text { Albumin/Creatinine }\end{array}$} & \multicolumn{2}{|c|}{ Uncontrolled DM (n= 42) } & \multicolumn{2}{|c|}{ Controlled DM $(\mathrm{n}=\mathbf{2 0})$} & \multicolumn{2}{|c|}{ Non DM $(n=20)$} \\
\hline & \multicolumn{2}{|c|}{ Urinary Type IV Collagen/Creatinine } & \multicolumn{2}{|c|}{ Urinary Type IV Collagen/Creatinine } & \multicolumn{2}{|c|}{ Urinary Type IV Collagen/Creatinine } \\
\hline & $\geq 4.2(n=21)$ & $<4.2(\mathrm{n}=21)$ & $\geq 4.2(n=2)$ & $<4.2(\mathrm{n}=18)$ & $\geq 4.2(n=1)$ & $<4.2(\mathrm{n}=19)$ \\
\hline$\geq 30$ & $11(52.4 \%)$ & $8(38.1 \%)$ & $1(50 \%)$ & $2(11.1 \%)$ & $0(0 \%)$ & $1(5.3 \%)$ \\
\hline$<30$ & $10(47.6 \%)$ & $13(61.9 \%)$ & $1(50 \%)$ & $16(88.9 \%)$ & $1(100 \%)$ & $18(94.7 \%)$ \\
\hline
\end{tabular}


One of the complications that often occur in individuals with DM is the development of DN condition to frank DM that will ultimately lead to terminal renal failure or ESRD. $(1,3,4)$

This study was carried out using some biomarkers that could be expected to detect the presence of renal impairment in patients with DM by observing the role of inflammation and the accumulation of ECM. Urinary albumin was used to determine the condition of albuminuria (urinary albumin $\geq 30 \mathrm{mg} / \mathrm{dL}$ ). In this study, second morning urine was used for measurement of urinary albumin, so that albumin excretion reported was in terms of the urinary albumin/ creatinine $(\mu \mathrm{g} / \mathrm{mg})$ ratio. Measurement of urinary GGT was used as a marker of cell membranes damage in tubules and urinary clusterin used a marker of cells damage in the tubulus proximal.(9)

Hyperglycemic condition will lead to increased nonenzymatic glycation process which can lead to inflammation and increased levels of hs-CRP. Therefore hs-CRP can be used to predict the onset of the inflammatory process induced by the glycation process on glycemic control in poorly controlled DM patients.(15) This study showed no significant diferences of the hs-CRP levels between the study groups. It was shown that mechanism of albuminuria may not occur directly through inflammatory mechanism.

Type IV collagen is the major constituent of the glomerular basement membrane and mesangium matrix. Increased glucose levels trigger generation of advanced glycation end products (AGEs) that will lead to the deposition of type IV collagen in the glomerular mesangial matrix due to increased synthesis of type IV collagen, but decay decreases, therefore type IV collagen level in the blood represents the rate of turnover of the ECM on kidney disease.(5)

$\mathrm{HbA1c}$ level in this study was used to assess glycemic control in diabetic patients, although with its limitations it can only show glycemic control of about 2-3 months earlier. This study found that HbAlc levels were positively correlated $(p<0.05)$ with urinary type IV collagen/creatinine ratio (Table 2). This significant correlation suggests that prolonged hyperglycemia condition is characterized by increased $\mathrm{HbA} 1 \mathrm{c}$ role in the formation of ECM.

To assess the risk factors for type IV collagen increase in uncontrolled DM $(\mathrm{HbA} 1 \mathrm{c} \geq 7)$ compared with controlled DM, cross-tabulation analysis was done and showed the odds ratio (OR) indicating increase of urinary type IV collagen was 9 folds in uncontrolled DM compared with that in the control. It means that the risk of ECM accumulation in uncontrolled DM was 9 times higher than in the controlled DM. It also showed the role of glucose control was essential to avoid the accumulation of ECM proteins as one of the mechanisms of kidney damage.

In this study we also found significant differences $(p<0.05)$ between urinary type IV collagen/creatinine ratio in uncontrolled DM subjects and controlled DM subjects and normal subjects, respectively, but no significant difference was found between controlled DM subjects with normal subjects. This shows the importance of glucose control in the prevention of complication development process of the disease.

In the subjects of uncontrolled DM, glucose levels were always high that will lead to increase nonenzymatic glycation process which will produce AGEs, and subsequently AGEs will stimulate formation of type IV collagen. Excess collagen formation not accompanied with swift breakdown causes accumulation of collagen in the glomerular basement membrane that leads to changes in the structure of the glomerulus.(5)

The study result is consistent with that of the study reported by Sthaneshwar and Chan who found that excretion of type IV collagen was higher in subjects with DM compared with that in non-DM subjects.(13)

Increased urinary albumin in $\mathrm{DN}$ is mainly derived from the glomerulus. The presence of albumin in the urine must be through the glomerular barrier filtration. (14) Presence of albumin in the urine is a sign of change in the glomerular structure due to accumulation of ECM, represented by the type IV collagen excretion into the urine. Accumulation of ECM causes changes in the size of mesangial membrane, increasing intraglomerulus pressure, loss of negatively charged glycosaminoglycans on the basal membrane of cells and subsequent enlargement of size of pores of the filtration membrane causes it to be impermeable to albumin, thus resulting in the occurrence of albuminuria. $(14,16)$

This study found that urinary albumin levels in uncontrolled DM group were significantly different $(p<0.05)$ from those in the controlled DM and normal group, but no significant difference $(p>0.05)$ was seen between controlled $\mathrm{DM}$ and normal subjects. This suggests that diabetic patients with good glycemic control may be considered to be in similar condition as the subjects who do not suffer from $\mathrm{DM}$, therefore it is very important for diabetic patients to have their blood glucose levels controlled to prevent kidney damage. As reported by Grainer et al., that poor glycemic control increases urinary albumin levels significantly in patients with DM compared with DM with good glycemic control.(17)

Table 4 showes that the risk factors for the occurrence of albuminuria in subjects with high HbAlc levels are 
7.44 times higher (95\% CI, 2.243-24.646, $\mathrm{p}<0.01$ ), and increase of urinary type IV collagen/creatinine to increased albuminuria showed 4.27 times greater $(95 \% \mathrm{CI}$ : 1.518 $12.028, p<0.05)$.

The frequency of albuminuria was found in approximately $50 \%$ of diabetic patients that were accompanied by elevated levels of urinary type IV collagen and this did not depend on whether the cases are uncontrolled or controlled DM (Table 5). It can be shown that urinary type IV collagen can also be used to assess kidney damage may even be used as a predictor of albuminuria in diabetic patients, but to confirm it, futher study is needed.

The significant correlation between $\mathrm{HbAlc}$ levels and the urinary type IV collagen/creatinine ratio $(p<0.01$, $\mathrm{r}=0528), \mathrm{HbA1} \mathrm{c}$ and urinary albumin $(p=0.019, \mathrm{r}=0.213)$, and urinary type IV collagen/creatinine ratio and urinary albumin ( $p=0.000, \mathrm{r}=0613$ ) in this study can be concluded as a fact that urinary type IV collagen is a promising marker in the future that can be used to detect kidney damage in patients with type $2 \mathrm{DM}$. However, to determine its sensitivity and specificity, it is necessary to conduct further study with more number of samples.

This study used multiple biomarkers of kidney damage that represent different areas of the functional unit of the kidney; the urinary albumin representing glomerular damage, urinary GGT representing damage to the proximal tubular cell membrane and urinary clusterin representing damage to the proximal tubular cells. Results of this study showed that $\mathrm{HbAlc}$ representing control of glucose levels in diabetic patients correlated significantly $(p<0.05)$ only with urine albumin, whereas both urinary GGT and urinary clusterin showed a non-significant correlation $(p>0.05)$. This suggests that kidney damage begins at the glomerulus in patients with DM before the onset of the damage of the cell membrane and proximal tubular cells.

Significant correlation of $\mathrm{HbAlc}$ levels and urinary type IV collagen/creatinine ratio with that reported that in DM subjects with microalbuminuria there was increase of the HbA1c levels.(18) Increased urinary excretion of type IV collagen in the subjects with albuminuria was also reported by Cohen et al. who found that the increase in urinary excretion of type IV collagen is an indicator of diabetic kidney disease which has entered the phase of compromised filtration function.(12) Ogawa et al. in an observational study over a 2-year period also found a significant correlation between the increase of urinary albumin/creatinine ratio to urinary type IV collagen and that in normoalbuminuria subjects, in which type IV collagen levels higher evolved into albuminuria within 2 years.(19)

This study found no correlation between $\mathrm{HbAlc}$ levels with urinary GGT (Table 3), as well as no significant correlation was found between urinary type IV collagen/ creatinine ratio and hs-CRP with urinary GGT. The role of GGT in this case was not likely occurs through inflammatory mechanisms and accumulation of ECM, to prove which a further study is needed.

The mechanism that involves in urinary GGT in kidney damage is still unclear. In the normal subjects, urinary enzymes of tubular epithelial cells are excreted into the urine in small amounts as a result of the metabolic activity of cells. Various conditions are harmful to the cells such as hypoxia, anoxia, ischemic and toxic effects of drugs followed by a decrease in renal function that will increase the number of tubular enzymes in urine. In diabetic patients, hyperglycemia can lead to increase in non-enzymatic glycation due to changes in energetic status. This will damage the cell membrane and cause the release of cells' cytoplasmic organelles into the lumen of the tubules.(20)

This study found no significant correlation $(p>0.05)$ between $\mathrm{HbA1c}$ levels and urinary clusterin, also between both hs-CRP and urinary type IV collagen/creatinine ratio and urinary clusterin. This suggests that the presence of chronic inflammation and accumulation of ECM is not correlated with urinary clusterin levels. It could be argued that the role of clusterin in this case is not possible through the mechanism of low-grade inflammation and overproduction of ECM. It is concluded therefore that the mechanism of clusterin involvement in DN is not clear, on which more studies are needed.

\section{Conclusion}

This study showed that albumin and type IV collagen in urine plays a role in the renal damage caused by uncontrolled glucose levels in type 2 DM patients. As one of the compilers of the extracellular matrix, urinary type IV collagen contributes to the accumulation of ECM, which is one mechanism of kidney damage. Increased urinary type IV collagen with increased urinary albumin may be a sign of glomerular damage. The increase of both HbAlc and urinary type IV collagen concentration indicates increase of the risk factor for glomerular damage. Urinary type IV collagen may be a future potential marker for detection of early renal damage.

\section{Acknowledgement}

We thank to The Prodia Education and Research Institute, Research Support Department of Prodia Clinical Laboratory, 
Prodia Clinical Laboratory - Makassar, and Prodia Clinical Laboratory - Panakukang for their invaluable supports in conducting this research.

\section{References}

1. Robertson RP. Chronic Oxidative Stress as a Central Mechanism for Glucose Toxicity in Pancreatic Islet Beta Cells in Diabetes. J Biol Chem. 2004; 272 (41): 42351-4.

2. Perkumpulan Endokrinologi Indonesia (PERKENI). Konsensus Pengelolaan dan Pencegahan Diabetes Mellitus Tipe 2 di Indonesia. 2011.

3. Ludirdja JS, Kencana L, Kurniawan K, Adyana MP, Aryana, IGPS. Rerata Durasi Penderita Diabetes Melitus Terkena Nefropati Diabetik Sejak Terdiagnosis Diabetes Melitus Pada Pasien Di Poliklinik Geriatri RSUP Sanglah. IPTEKMA 2 2010; 1: 15-9.

4. Luis-Rodríguez D, Martínez-Castelao A, Górriz JL, De-Álvaro F, Navarro-González JF. Pathophysiological Role and Therapeutic Implication of Inflammation in Diabetic Nephropathy. World J Diabetes. 2012; 3: 7-18.

5. Cohen-Bucay A, Viswanathan G. Urinary Markers of Glomerular Injury in Diabetic Nephropathy. Int J Nephrol. 2012; 2012: 146987.

6. Arya A, Aggarwal S, Yadav HN. Pathogenesis of Diabetic Nephropathy. Int J Pharm Pharm Sci. 2010; 2: 24-9.

7. QianY, Feldman E, Pennathur S, Kretzler M, Brosius FC. Mechanism of Diabetic Glomerulosclerosis. Diabetes. 2008; 57: 1439-46.

8. Gatua WK, Makumi JN, Njagi EM, Kigondu, CS, Mcligeyo SO, Waithaka SK. Evaluation of Urinary Tubular Enzymes as Screening Markers of Renal Disfunction in Patients Suffering from Diabetes Mellitus. Asian J Med Sci. 2011; 3: 84- 90.

9. Fuchs TC, Hewitt P. Preclinical Perspective of Urinary Biomarkers for the Detection of Nephrotoxicity: What We Know and What We Need to Know. Biomark Med. 2011; 5: 763-79.

10. Solichova P, Karpisek M, Ochmanova R, Hanulova Z, Humenanska $\mathrm{V}$, Stejskal D, et al. Urinary Clusterin Concentration-A Possible Marker of Nephropathy? Pilot Studi. Biomed Pab Med Fac Univ Palacky Olomouc Czech Repub. 2007; 151: 233-6.

11. Hidaka S, Kränzlin B, Gretz N, Witzgall R. Urinary Clusterin Level in the Rat Correlate with the Severity of Tubular Damage and May Help to Differentiate Between Glomerular and Tubular Injuries. Cell Tissue Res. 2002; 310: 289-96.

12. Cohen MP, Shearman CW, Lautenslager GT. Serum Type IV Collagen in Diabetic Patients at Risk for Nephropathy. Diabetes Care. 2001; 24: 1324-7.

13. Sthaneshwar P, Chan SP. Urinary type IV Collagen Levels in Diabetes Mellitus. Malays J Pathol. 2010; 32: 43-7.

14. Sahib MN, Abdulameer SA, Aziz NA, Hassan Y. Pathogenesis of Diabetic Kidney Disease: Review of Cellular Aspects of Renal Lesions. Afr J Pharm Pharmacol. 2009; 3: 507-14.

15. Roopakala MS, Pawan HR, Krisnhamurthy U, Wilmadelphine S, Eshwarappa M, Kumar KMP. Evaluation of High Sensitivity C-Rective Protein and Glycated Hemoglobin Levels in Diabetic Nephropathy. Saudi J Kidney Dis Transpl. 2012; 23: 286-9.

16. Mohammadi-Karakani A, Asgharzadeh-Haghighi S, Ghazi-Khansari M, Hosseni R. Determination of Urinary Enzymes as a Marker of Early Renal Damage in Diabetic Patients. J Clin Lab Anal. 2007; 21: 413-7.

17. Granier C, Makni K, Molina L, Jardin-Watelet B, Ayadi H, Jaraya F. Gene and Protein Markers of Diabetic Nephropathy. Nephrol Dial Transplant. 2008; 23: 792-9.

18. Khan MI, Usman K, Ashfaq F, Himanshu D, Ali W, Idris MZ. Association of hsCRP with Microalbuminuria in Type-2 Diabetic
Patients in North India. Biomed Res. 2012; 23: 380-4.

19. Ogawa S, Matsushima M, Okamura M, Senda M, Sakamoto T, Nako $\mathrm{K}$, et al. Urinary Type IV Collagen Excretion Predicts an Increased Urinary-to-Creatinin Ratio in Normoalbuminuric Patients with Diabetes. J Diabetes Mellitus. 2012; 2: 413-26.

20. Vlatković V, Stojimirović B, Obrenović R. Damage of Tubule Cells in Diabetic Nephropathy Type 2: Urinary N-Acetyl$\beta$-D-Glukosaminidasis and Gamma-Glutamyl-Transferasis. Vojnosanitetski Pregled. 2007; 64: 123-7. 